\title{
Modifikasi Perencanaan Gedung RSUD Koja Jakarta Menggunakan Struktur Komposit Baja- Beton dengan Base Isolator : High Damping Rubber Bearing
}

\author{
Aziiz Dwi Wicaksono dan Endah Wahyuni \\ Departemen Teknik Sipil, Fakultas Teknik Sipil dan Perencanaan, Institut Teknologi Sepuluh Nopember (ITS)
} e-mail: endah@ce.its.ac.id

\begin{abstract}
Abstrak-Struktur komposit baja-beton saat ini telah banyak digunakan dalam pembangunan konstruksi sipil. Hal ini dikarenakan struktur komposit baja-beton memiliki keunggulan dibanding dengan struktur beton bertulang biasa, diantaranya yaitu, penghematan berat baja, mengurangi penampang balok baja, meningkatkan kekuatan pelat lantai, meningkatkan kapasitas pemikul beban, menambah bentang pada bentang tertentu. Penggunaan teknologi Base Isolator sebagai peredam gempa juga dinilai sangat penting bagi konstruksi bangunan gedung karena mengurangi gaya gempa yang diterima oleh struktur. Rumah Sakit Umum Daerah (RSUD) Koja Jakarta pada kondisi sebenarnya dibangun menggunakan struktur beton bertulang biasa dan memiliki 16 lantai. Dalam studi ini, gedung tersebut akan dimodifikasi menggunakan struktur komposit baja-beton dengan Base Isolator : High Damping Rubber Bearing (HDRB) yang pembebanannya mengacu SNI 1727:2013 dan PPIUG 1983. Perencanaan yang dilakukan meliputi perencanaan struktur sekunder, struktur primer, base isolator, sambungan, dan pondasi. Dari analisa dan perhitungan diperoleh hasil, yaitu: tebal pelat atap $9 \mathrm{~cm}$, pelat lantai $9 \mathrm{~cm}$, dimensi balok anak terbesar WF400x200x8x13, dimensi balok induk 500x200x11x19, dimensi kolom terbesar K700x300x13x24 terselubung beton $850 \times 850$, base isolator HDRB dengan diameter rubber $750 \mathrm{~mm}$, pondasi menggunakan tiang pancang spun pile diameter $60 \mathrm{~cm}$ dengan kedalaman 26 meter. Perhitungan tersebut memenuhi persyaratan keamanan struktur berdasarkan SNI 1726:2012, SNI 1729:2015, SNI 031729-2002, dan SNI 2847:2013.
\end{abstract}

Kata Kunci-Struktur Komposit Baja-Beton, Rumah Sakit, Base Isolator, High Damping Rubber Bearing.

\section{PENDAHULUAN}

\section{A. Latar Belakang}

Jakarta terletak pada lempeng tektonik Eurasia. Di Selatan-Barat Daya Jakarta terdapat patahan tempat pertemuan lempeng Eurasia dengan lempeng Indo-Australia yang menghujam dan bergerak dengan kecepatan $\pm 60 \mathrm{~mm}$ per tahun. Patahan Sumatera dan patahan Jawa inilah yang merupakan sumber gempa terbesar yang dapat mempunyai dampak terhadap Jakarta [1]. Klasifikasi tanah Jakarta pada umumnya dapat dikelompokkan ke dalam kelas lokasi SD (tanah sedang) dan SE (tanah lunak) [2], dan gempa yang terjadi di Jakarta secara umum merupakan gempa kiriman dari daerah lain, misal Sumatera. Sehingga Jakarta tergolong wilayah gempa sedang. Tergolong dalam wilayah gempa sedang, bukan berarti Jakarta sudah "aman" terhadap gempa. Berdasarkan indeks penduduk terpapar $\left(\mathrm{jiwa} / \mathrm{km}^{2}\right) \mathrm{di}$ Propinsi DKI Jakarta, gempa tergolong parameter yang tinggi. Berarti gempa yang terjadi sangat berdampak pada penduduk Propinsi DKI Jakarta, kerugian yang ditimbulkan akibat gempa pun juga tergolong tinggi dalam indeks kerugian (dalam rupiah) bencana di DKI Jakarta.

Sebagai objek studi, dipilih gedung Rumah Sakit Umum Daerah (RSUD) Koja yang berlokasi di Jakarta. Gedung ini memiliki 16 lantai dan dibangun menggunakan beton bertulang biasa. Dengan memperhatikan kemungkinan penambahan kapasitas ruang pelayanan di kemudian hari, maka diperlukan modifikasi bangunan menggunakan struktur komposit baja-beton. Struktur komposit baja-beton merupakan gabungan beton dengan baja profil, dimana pada beton bertulang gaya-gaya tarik dipikul oleh besi tulangan [3]. Tapi pada komposit baja-beton ini gaya-gaya tarik langsung dipikul oleh profil baja. Dengan demikian, struktur komposit baja-beton memiliki kapasitas pemikul beban lebih besar daripada struktur beton bertulang maupun struktur baja biasa [4].

Gedung RSUD Koja yang berfungsi sebagai rumah sakit tergolong bangunan dengan fungsi keutamaan tinggi, sehingga perlu didesain tahan terhadap gempa. Seiring dengan perkembangan teknologi, salah satu metode yang dapat meredam energi gempa adalah dengan base isolator. Konsep dari base isolator sendiri adalah berusaha "memisahkan" bangunan dari gerakan horisontal pondasi dengan memasang peralatan isolator diantara kolom dan pondasi. Base isolator mempunyai sifat yang fleksibel terhadap gaya horisontal, tapi mampu menahan berat bangunan dengan baik. Hal itu dikarenakan kombinasi antara material karet dan pelat baja yang tersusun. Dengan sifat fleksibel tersebut, saat gaya gempa menggeser pondasi, base isolator melakukan simpangan horisontal bolak-balik dari tanah sehingga gaya tersebut hanya sebagian kecil yang diterima ke struktur bangunan [5]. Secara umum base isolator terdiri dari beberapa jenis, yaitu: (1) Laminated Rubber (Elastomeric) Bearing, (2) Lead Rubber Bearing (LBR), (3) High Damping Rubber Bearing (HDRB), (4) Friction Pendulum System (FPS) [6].

\section{B. Rumusan Masalah}

Masalah yang akan dibahas dalam studi ini adalah sebagai berikut:

1. Bagaimana merencanakan struktur sekunder yang meliputi pelat, balok anak, tangga, ramp, dan lift?

2. Bagaimana merencanakan struktur primer gedung menggunakan komposit baja-beton dengan peraturan yang berlaku?

3. Bagaimana merencanakan Base Isolator : High Damping Rubber Bearing (HDRB)? 
4. Bagaimana merencanakan pondasi sesuai dengan beban yang dipikul struktur?

5. Bagaimana menjelaskan hasil akhir perencanaan modifikasi dalam bentuk gambar teknik?

\section{Batasan Masalah}

Batasan masalah dalam penulisan studi ini adalah sebagai berikut:

1. Base Isolator menggunakan tipe High Damping Rubber Bearing (HDRB).

2. Analisa struktur menggunakan program SAP 2000.

3. Tidak membuat metode pelaksanaan di lapangan, arsitektural, manajemen konstruksi, dan perhitungan analisa biaya.

4. Perencanaan tidak meliputi instalasi mechanical electrical, dan sanitasi.

\section{TINJAUAN PUSTAKA}

\section{A. Base Isolator Elastomeric Rubber Bearing}

Base isolator merupakan sebuah bantalan karet berkekuatan tinggi yang dipasang diantara pondasi dan bangunan. Sistem ini bekerja dengan menjaga struktur diatasnya sebagai satu kesatuan. Pada saat terjadi gempa,masing-masing struktur bangunan akan bergetar akibat dari pergerakan tanah yang mempengaruhi pondasi bangunan. Karena pergerakan tanah yang terjadi bersifat acak maka getaran yang memasuki struktur juga tidak selaras, hal ini menyebabkan bangunan yang bersifat kaku mudah runtuh.
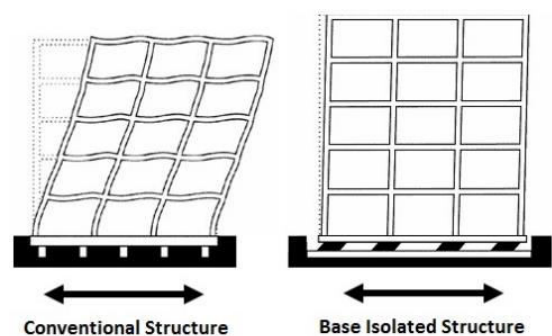

Gambar 1. Perbandingan Perilaku Gedung Menggunakan Base Isolator dan Fixed Base.

Pada bangunan yang menggunakan base isolator, getaran yang terjadi pada pondasi akan melewati bantalan karet terlebih dahulu sebelum memasuki sistem struktur. Karena karet bersifat elastis maka arah getaran yang terjadi secara acak hanya akan mempengaruhi base isolator, sedangkan struktur diatasnya akan bergetar atau bergerak sebagai satu kesatuan struktur [7]. Perbandingan antara bangunan konvensional dengan bangunan yang menggunakan base isolator dapat dilihat pada Gambar 1.

High damping rubber bearing (Gambar 2) merupakan bahan anti seismik yang dikembangkan dari karet alam yang mempunyai kekakuan horizontal yang relatif kecil dan dicampur dengan extra fine carbon block, oil atau resin, serta bahan isian lainnya sehingga meningkatkan damping antara $10 \%-20 \%$.

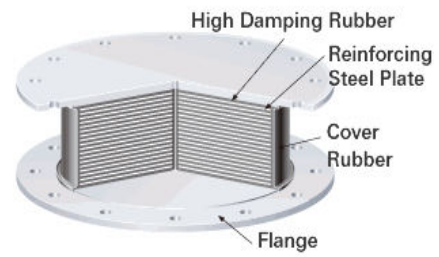

Gambar 2. High Damping Rubber Bearing

\section{METODOLOGI}

\section{A. Bagan Alir Penyelesaian studi}

Berikut adalah langkah-langkah dalam mengerjakan studi ini yang digambarkan dalam diagram alir pada Gambar 3.

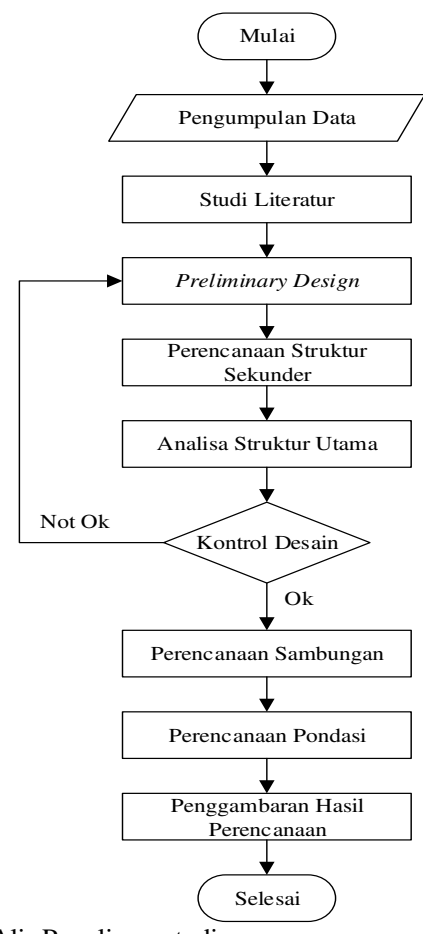

Gambar 3. Diagram Alir Penulisan studi.

\section{B. Data Perencanaan}

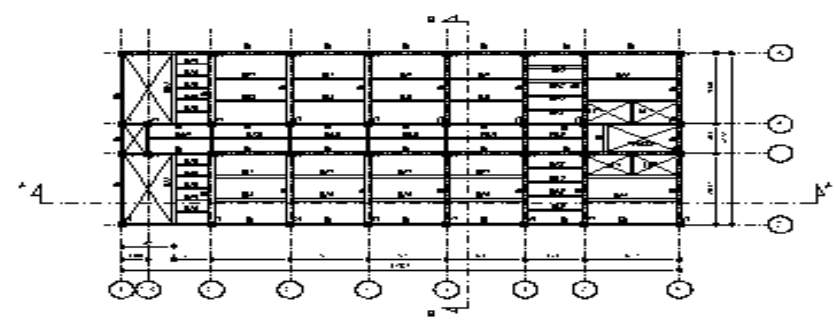

Gambar 4. Denah Pembalokan.

Data modifikasi perencanaan studi ini adalah sebagai berikut:

- $\quad$ Nama gedung = RSUD Koja Jakarta

- Lokasi = Jl. Deli no. 4, Jakarta Utara

- Fungsi = Rumah Sakit

- Jumlah Lantai $=16$ Lantai

- Struktur menggunakan komposit baja-beton (kolom profil king cross terselubung beton dan balok komposit menggunakan steel deck) dengan base isolator tipe High Damping Rubber Bearing (HDRB)

- Mutu baja BJ 41 dan f'c $30 \mathrm{MPa}$

- $\quad$ Sistem penahan lateral adalah SRPMK 


\section{ANALISA DAN HASIL}

\section{A. Perhitungan Struktur Sekunder}

Perhitungan struktur sekunder meliputi pelat, balok anak, balok lift, tangga, dan ramp [8][9][10][11][12], dan [13].

1) Pelat

Perencanaan pelat lantai dan atap pada studi ini menggunakan steel deck dari "Super Floor Deck" dengan tebal $0,75 \mathrm{~mm}$. Hasil perhitungan dapat dilihat pada Tabel 1. Tabel 1.

Dimensi dan Penulangan Pelat

\begin{tabular}{cccc}
\hline \hline Jenis Pelat & Bentang $(\mathrm{m})$ & $\begin{array}{c}\text { Tebal Pelat } \\
(\mathrm{cm})\end{array}$ & $\begin{array}{c}\text { Tulangan } \\
\text { Negatif }\end{array}$ \\
\hline Atap & 2,67 & 9 & $\varnothing 10-200$ \\
Lantai & 2,67 & 9 & $\varnothing 10-160$ \\
\hline \hline
\end{tabular}

\section{2) Balok Anak}

Balok anak pada studi ini menggunakan profil WF dengan mutu baja BJ 41. Hasil perhitungan balok anak atap dan lantai dapat dilihat pada Tabel 2.

Tabel 2.

Dimensi Balok Anak

\begin{tabular}{|c|c|c|}
\hline Nama Balok & Panjang (m) & Dimensi Balok \\
\hline BA1 & 6 & WF $350 \times 175 \times 6 \times 9$ \\
\hline BA2 & $4,575 \& 4,875$ & WF 200x150x6x9 \\
\hline BA3 & 6 & WF $250 \times 175 \times 7 \times 11$ \\
\hline BA4 & $7,275 \& 8$ & WF $350 \times 175 \times 7 \times 11$ \\
\hline BA5 & 6 & WF $250 \times 175 \times 7 \times 11$ \\
\hline BA6 & 4,575 & WF $200 \times 150 \times 6 \times 9$ \\
\hline BA7 & 6 & WF $250 \times 125 \times 6 \times 9$ \\
\hline BA8 & $7,275 \& 6,875$ & WF $350 \times 175 \times 6 \times 9$ \\
\hline BA9 & 2,875 & WF $125 \times 60 \times 6 \times 8$ \\
\hline
\end{tabular}

3) Balok Lift

Pada studi ini, spesifikasi lift menggunakan produk sigma elevator company dengan kapasitas 15 orang (1000 $\mathrm{kg}$ ). Didapatkan balok penggantung lift menggunakan profil WF $300 \times 150 \times 5,5 \times 8$.

4) Tangga studi ini:

Berikut data teknis tangga yang digunakan dalam

- Tinggi antar lantai $=4 \mathrm{~m} \quad$ - Tinggi bordes $=2 \mathrm{~m}$

- Tinggi injakan $=15,3 \mathrm{~cm} \quad$ - Lebar injakan $=30 \mathrm{~cm}$

- Jumlah tanjakan $=13 \quad$ - Jumlah injakan $=12$

- Lebar bordes $\quad=1,6 \mathrm{~m} \quad$ - Panjang bordes $=3,3 \mathrm{~m}$

- Panjang tangga $=3,9 \mathrm{~m} \quad$ - Lebar tangga $=1,55 \mathrm{~m}$

- Kemiringan tangga $=27,15^{\circ}$

Hasil perhitungan perencanaan tangga dapat dilihat pada Tabel 3.

Tabel 3.

Rekapitulasi Hasil Perencanaan Tangga

\begin{tabular}{|c|c|}
\hline Elemen & Keterangan \\
\hline Pelat anak tangga & Baja tebal $=4 \mathrm{~mm}$ \\
\hline Pelat bordes & Baja tebal $=5 \mathrm{~mm}$ \\
\hline Penyangga pelat injak & L 50x50x9 \\
\hline Balok bordes tangga & WF $100 \times 50 \times 5 \times 7$ \\
\hline Balok utama tangga & WF $250 \times 125 \times 5 \times 8$ \\
\hline Balok penumpu tangga & WF $250 \times 125 \times 5 \times 8$ \\
\hline
\end{tabular}

5) Ramp

Berikut data teknis ramp yang digunakan dalam studi ini:

- Tinggi antar lantai $=4 \mathrm{~m} \quad$ - Panjang ramp $=6 \mathrm{~m}$

- Tinggi bordes $=1 \mathrm{~m} \quad$ - Lebar ramp $=1,9 \mathrm{~m}$

- Lebar bordes $\quad=2 \mathrm{~m} \quad$ - Kemiringan ramp $=9,46^{\circ}$

- Panjang bordes $=4 \mathrm{~m}$

Hasil perhitungan perencanaan ramp dapat dilihat pada Tabel 4.

Tabel 4.

Rekapitulasi Hasil Perencanaan Ramp

\begin{tabular}{|c|c|}
\hline Elemen & Keterangan \\
\hline Pelat lantai & Tebal $=9 \mathrm{~cm}$ \\
\hline Pelat bordes & Tebal $=9 \mathrm{~cm}$ \\
\hline Balok bordes ramp & WF $100 \times 50 \times 5 \times 7$ \\
\hline Balok utama ramp & WF $350 \times 175 \times 6 \times 9$ \\
\hline Balok penumpu ramp & WF $350 \times 175 \times 6 \times 9$ \\
\hline
\end{tabular}

\section{B. Analisa Struktur Fixed Base}

Hasil dari analisa fixed base ini adalah nilai gaya aksial kolom terbesar yang akan digunakan untuk perencanaan dimensi base isolator dan sudah memenuhi kontrol sesuai dengan persyaratan [9].

1) Kontrol Simpangan Antar Lantai (Drift)

Simpangan antar lantai $(\Delta)$ dihitung sebagai perbedaan defleksi pada pusat massa di tingkat teratas dan terbawah yang ditinjau. Kontrol simpangan arah $\mathrm{X}$ dapat dilihat pada Tabel 5 dan kontrol simpangan arah $\mathrm{Y}$ dapat dilihat pada Tabel 6.

Tabel 5.

Kontrol Simpangan X Antar Lantai Akibat Beban Gempa Arah X Struktur Fixed Base

\begin{tabular}{cccccccc}
\hline \hline Keterangan & $\begin{array}{c}\text { hi } \\
\mathrm{mm}\end{array}$ & $\begin{array}{c}\delta \mathrm{xe} \\
\mathrm{mm}\end{array}$ & $\begin{array}{c}\delta \mathrm{x} \\
\mathrm{mm}\end{array}$ & $\begin{array}{c}\Delta=\delta \mathrm{xa}-\delta \mathrm{xb} \\
\mathrm{mm}\end{array}$ & $\begin{array}{c}\Delta \mathrm{a} \\
\mathrm{mm}\end{array}$ & $\begin{array}{c}\Delta \mathrm{a} / \rho \\
\mathrm{mm}\end{array}$ & $\begin{array}{c}\Delta \leq \\
\Delta \mathrm{a} / \rho\end{array}$ \\
\hline Atap & 4000 & 145.37 & 533.01 & 9.75 & 60 & 60 & $\mathrm{OK} !$ \\
Lantai 16 & 4000 & 142.71 & 523.26 & 14.14 & 60 & 60 & $\mathrm{OK} !$ \\
Lantai 15 & 4000 & 138.85 & 509.12 & 19.03 & 60 & 60 & $\mathrm{OK} !$ \\
Lantai 14 & 4000 & 133.66 & 490.09 & 23.86 & 60 & 60 & $\mathrm{OK} !$ \\
Lantai 13 & 4000 & 127.15 & 466.22 & 28.71 & 60 & 60 & $\mathrm{OK} !$ \\
Lantai 12 & 4000 & 119.32 & 437.52 & 31.54 & 60 & 60 & $\mathrm{OK!}$ \\
Lantai 11 & 4000 & 110.72 & 405.98 & 34.98 & 60 & 60 & $\mathrm{OK!}$ \\
Lantai 10 & 4000 & 101.18 & 371.00 & 38.46 & 60 & 60 & $\mathrm{OK!}$ \\
Lantai 9 & 4000 & 90.69 & 332.54 & 41.81 & 60 & 60 & $\mathrm{OK} !$ \\
Lantai 8 & 4000 & 79.29 & 290.73 & 45.00 & 60 & 60 & $\mathrm{OK} !$ \\
Lantai 7 & 4000 & 67.02 & 245.73 & 45.96 & 60 & 60 & $\mathrm{OK} !$ \\
Lantai 6 & 4000 & 54.48 & 199.77 & 47.15 & 60 & 60 & $\mathrm{OK} !$ \\
Lantai 5 & 4000 & 41.63 & 152.63 & 47.12 & 60 & 60 & $\mathrm{OK!}$ \\
Lantai 4 & 4000 & 28.78 & 105.51 & 44.63 & 60 & 60 & $\mathrm{OK!}$ \\
Lantai 3 & 4000 & 16.60 & 60.88 & 37.57 & 60 & 60 & $\mathrm{OK} !$ \\
Lantai 2 & 5000 & 6.36 & 23.31 & 23.31 & 75 & 75 & $\mathrm{OK} !$ \\
Lantai 1 (Dasar) & 0 & 0.00 & 0.00 & 0.00 & 0 & 0 & - \\
\hline \hline
\end{tabular}

Tabel 6.

Kontrol Simpangan Y Antar Lantai Akibat Beban Gepma Arah Y Struktur Fixed Base

\begin{tabular}{cccccccc}
\hline \hline Keterangan & $\begin{array}{c}\mathrm{hi} \\
\mathrm{mm}\end{array}$ & $\begin{array}{c}\delta \mathrm{xe} \\
\mathrm{mm}\end{array}$ & $\delta \mathrm{x} \mathrm{mm}$ & $\begin{array}{c}\Delta=\delta \mathrm{xa}-\delta \mathrm{xb} \\
\mathrm{mm}\end{array}$ & $\begin{array}{c}\Delta \mathrm{mm} \\
\mathrm{mm}\end{array}$ & $\begin{array}{c}\Delta \mathrm{a} / \rho \\
\mathrm{mm}\end{array}$ & $\begin{array}{c}\Delta \leq \\
\Delta \mathrm{a} / \rho\end{array}$ \\
\hline Atap & 4000 & 162.28 & 595.01 & 16.61 & 60 & 60 & $\mathrm{OK} !$ \\
Lantai 16 & 4000 & 157.75 & 578.40 & 21.14 & 60 & 60 & $\mathrm{OK} !$ \\
Lantai 15 & 4000 & 151.98 & 557.26 & 25.91 & 60 & 60 & $\mathrm{OK} !$ \\
Lantai 14 & 4000 & 144.92 & 531.36 & 30.46 & 60 & 60 & $\mathrm{OK} !$ \\
Lantai 13 & 4000 & 136.61 & 500.90 & 34.87 & 60 & 60 & $\mathrm{OK!}$ \\
Lantai 12 & 4000 & 127.10 & 466.03 & 37.27 & 60 & 60 & $\mathrm{OK!}$ \\
Lantai 11 & 4000 & 116.93 & 428.75 & 40.15 & 60 & 60 & $\mathrm{OK!}$ \\
Lantai 10 & 4000 & 105.98 & 388.61 & 43.02 & 60 & 60 & $\mathrm{OK!}$ \\
\hline \hline
\end{tabular}




\begin{tabular}{cccccccc}
\hline \hline Lantai 9 & 4000 & 94.25 & 345.59 & 45.74 & 60 & 60 & OK! \\
Lantai 8 & 4000 & 81.78 & 299.85 & 48.23 & 60 & 60 & OK! \\
Lantai 7 & 4000 & 68.62 & 251.62 & 48.71 & 60 & 60 & OK! \\
Lantai 6 & 4000 & 55.34 & 202.91 & 49.29 & 60 & 60 & OK! \\
Lantai 5 & 4000 & 41.90 & 153.62 & 48.52 & 60 & 60 & OK! \\
Lantai 4 & 4000 & 28.67 & 105.11 & 45.20 & 60 & 60 & OK! \\
Lantai 3 & 4000 & 16.34 & 59.91 & 37.33 & 60 & 60 & OK! \\
Lantai 2 & 5000 & 6.16 & 22.58 & 22.58 & 75 & 75 & OK! \\
Lantai 1 & 0 & 0.00 & 0.00 & 0.00 & 0 & 0 & - \\
(Dasar) & & & & & & & \\
\hline \hline
\end{tabular}

$$
\mathrm{Vs}=\frac{\mathrm{K}_{\mathrm{Dmax}} \times \mathrm{D}_{\mathrm{D}}}{\mathrm{R}}
$$

Didapatkan nilai $\mathrm{V}_{\mathrm{S}}=465255 \mathrm{~kg}$. Gaya gempa dinamis $\geq$ $0,8 \mathrm{Vs}=372204,01 \mathrm{~kg}$. Dari hasil SAP2000, didapatkan gaya gempa dinamis seperti Tabel 7.

\begin{tabular}{ccc} 
& Tabel 7. \\
& Gaya Gempa Dinamis Struktur Isolasi \\
\hline \hline Arah Gempa & Beban Gempa $(\mathrm{kg})$ & Keterangan \\
& & $(\mathrm{Vt} \geq 0,8 \mathrm{Vs})$ \\
\hline Arah X & 572517,7 & OK \\
Arah Y & 542409,11 & OK \\
\hline \hline
\end{tabular}

Dari hasil tabel diatas maka analisa pemodelan struktur memenuhi persyaratan.

2) Kontrol Waktu Getar Alami Fundamental

Pada studi ini didapatkan nilai periode getar alami

Dengan hasil diatas, maka memenuhi persyaratan. Tabel 8.

Kontrol Simpangan X Antar Lantai Akibat Beban Gempa Arah X Struktur

fundamental ijin adalah 2,858 detik. Periode struktur dar software SAP2000 didapatkan sebesar 2,208 detik $<2,858$ detik, sehingga memenuhi syarat.

\section{Analisa Struktur Isolasi}

Pada Struktur Isolasi diwajibkan memiliki ruang pemerikasaan dan penggantian base isolator [9]. Pada studi ini tinggi ruang pemeriksaan direncanakan 2,5 $\mathrm{m}$.

Nilai $T_{M} \leq 3$ detik dan nilai $T_{D} \geq 3 \times T_{\text {fixedbase }}$ [9]. Hasil dari SAP2000, didapat $T=3,33$ detik $\geq 3$ detik sehingga $T_{M}=3$ detik, sedangkan nilai $\mathrm{T}_{\mathrm{D}}=3 \times 2,208=6,62$ detik.

Nilai $R$ (faktor reduksi gempa) $=2$, untuk faktor keutamaan gempa $=1$. Damping ratio $=0,24$, nilai koefisien redaman $\mathrm{B}_{\mathrm{D}}$ atau $\mathrm{B}_{\mathrm{M}}$ adalah 1,58 (interpolasi) [9].

1) Dimensi HDRB

Pada analisa struktur fixed base, didapatkan gaya aksial kolom terbesar $(\mathrm{w})=8058350 \mathrm{~N}$. Direncanakan spesifikasi HDRB menggunakan brosur bridgestone. Berikut adalah tahapan perhitungan dimensi HDRB [14]:

Mencari kekakuan horisontal $\left(\mathrm{K}_{\mathrm{H}}\right)$

$$
\begin{aligned}
\mathrm{K}_{\mathrm{H}} & =\frac{\mathrm{w} \times\left(\frac{2 \pi}{\mathrm{T}_{\mathrm{D}}}\right)}{\text { Pjg.bentang }}=\frac{8058350 \times\left(\frac{2 \pi}{6,62}\right)}{6000} \\
& =1209,07 \mathrm{~N} / \mathrm{mm}
\end{aligned}
$$

- $\quad$ Luasan HDRB

$$
\begin{aligned}
& A=\frac{K_{H} \times \operatorname{tr}}{G}=\frac{1209,07 \times 200}{0,62}=390022,18 \mathrm{~mm}^{2} \\
& D=704,55 \mathrm{~mm} \text {, pakai } 750 \mathrm{~mm}
\end{aligned}
$$

2) Kontrol Simpangan Antar Lantai (Drift)

Simpangan antar lantai maksimum dari struktur di atas sistem isolasi yang dihitung dengan analisis spektrum respon tidak boleh melebihi $0,015_{\mathrm{hx}}$ dan faktor $\mathrm{Cd}$ dari struktur dengan isolasi sama dengan faktor R [9]. Kontrol simpangan arah $\mathrm{X}$ dapat dilihat pada Tabel 8 dan kontrol simpangan arah Y dapat dilihat pada Tabel 9.

3) Kontrol Perpindahan Base Isolator

Perpindahan maksimum base isolator $\left(\mathrm{D}_{\mathrm{M}}{ }_{\mathrm{M}}\right)=307$ $\mathrm{mm}$. Untuk gempa arah $\mathrm{X}$, perpindahan base isolator $=$ $241,08 \mathrm{~mm} \leq 307 \mathrm{~mm}$ (OK!) sedangkan untuk gempa arah $\mathrm{Y}$, perpindahan base isolator $=219,41 \mathrm{~mm} \leq 307 \mathrm{~mm}$ (OK!). Jadi perpindahan maksimum base isolator memenuhi persyaratan [9].

4) Kontrol Nilai Akhir Respon Spektrum

\begin{tabular}{|c|c|c|c|c|c|c|c|}
\hline Keterangan & hi mm & $\begin{array}{l}\delta x e \\
m m\end{array}$ & $\delta \mathrm{x} \mathrm{mm}$ & $\begin{array}{c}\Delta=\delta x a-\delta x b \\
m m\end{array}$ & $\begin{array}{c}\Delta \mathrm{a} \\
\mathrm{mm}\end{array}$ & $\begin{array}{l}\Delta \mathrm{a} / \rho \\
\mathrm{mm}\end{array}$ & $\begin{array}{c}\Delta \leq \\
\Delta \mathrm{a} / \rho\end{array}$ \\
\hline Atap & 4000 & 260.72 & 521.43 & 4.07 & 60 & 60 & $\mathrm{OK} !$ \\
\hline Lantai 16 & 4000 & 258.68 & 517.36 & 5.72 & 60 & 60 & $\mathrm{OK} !$ \\
\hline Lantai 15 & 4000 & 255.82 & 511.64 & 7.67 & 60 & 60 & $\mathrm{OK} !$ \\
\hline Lantai 14 & 4000 & 251.99 & 503.98 & 9.70 & 60 & 60 & $\mathrm{OK} !$ \\
\hline Lantai 13 & 4000 & 247.14 & 494.27 & 11.88 & 60 & 60 & $\mathrm{OK} !$ \\
\hline Lantai 12 & 4000 & 241.20 & 482.39 & 13.33 & 60 & 60 & $\mathrm{OK} !$ \\
\hline Lantai 11 & 4000 & 234.53 & 469.06 & 15.07 & 60 & 60 & $\mathrm{OK} !$ \\
\hline Lantai 10 & 4000 & 227.00 & 454.00 & 16.90 & 60 & 60 & OK! \\
\hline Lantai 9 & 4000 & 218.55 & 437.10 & 18.79 & 60 & 60 & OK! \\
\hline Lantai 8 & 4000 & 209.15 & 418.31 & 20.81 & 60 & 60 & OK! \\
\hline Lantai 7 & 4000 & 198.75 & 397.50 & 21.95 & 60 & 60 & $\mathrm{OK} !$ \\
\hline Lantai 6 & 4000 & 187.78 & 375.56 & 23.39 & 60 & 60 & OK! \\
\hline Lantai 5 & 4000 & 176.08 & 352.16 & 24.84 & 60 & 60 & $\mathrm{OK} !$ \\
\hline Lantai 4 & 4000 & 163.66 & 327.32 & 26.12 & 60 & 60 & OK! \\
\hline Lantai 3 & 4000 & 150.60 & 301.20 & 26.97 & 60 & 60 & OK! \\
\hline Lantai 2 & 5000 & 137.11 & 274.23 & 33.15 & 75 & 75 & OK! \\
\hline antai 1 (Dasar) & 0 & 120.54 & 241.08 & - & 0 & 0 & - \\
\hline
\end{tabular}

Gaya geser statik (Vs) untuk elemen struktur diatas sistem isolasi [9] adalah: Isolasi

\begin{tabular}{|c|c|c|c|c|c|c|c|}
\hline Keterangan & hi mm & $\begin{array}{l}\delta x e \\
\mathrm{~mm}\end{array}$ & $\delta \mathrm{x} \mathrm{mm}$ & $\begin{array}{c}\Delta=\underset{\mathrm{xa}-\delta \mathrm{xb}}{\mathrm{mm}} \\
\end{array}$ & $\begin{array}{c}\Delta \mathrm{a} \\
\mathrm{mm}\end{array}$ & $\begin{array}{c}\Delta \mathrm{a} / \rho \\
\mathrm{mm}\end{array}$ & $\begin{array}{c}\Delta \leq \\
\Delta \mathrm{a} / \rho\end{array}$ \\
\hline Atap & 4000 & 276.43 & 552.85 & 7.73 & 60 & 60 & $\mathrm{OK!}$ \\
\hline Lantai 16 & 4000 & 272.56 & 545.13 & 9.62 & 60 & 60 & OK! \\
\hline Lantai 15 & 4000 & 267.75 & 535.50 & 11.67 & 60 & 60 & $\mathrm{OK} !$ \\
\hline Lantai 14 & 4000 & 261.92 & 523.84 & 13.75 & 60 & 60 & OK! \\
\hline Lantai 13 & 4000 & 255.05 & 510.09 & 15.91 & 60 & 60 & OK! \\
\hline Lantai 12 & 4000 & 247.09 & 494.18 & 17.29 & 60 & 60 & $\mathrm{OK} !$ \\
\hline Lantai 11 & 4000 & 238.45 & 476.89 & 18.90 & 60 & 60 & $\mathrm{OK} !$ \\
\hline Lantai 10 & 4000 & 229.00 & 457.99 & 20.58 & 60 & 60 & $\mathrm{OK} !$ \\
\hline Lantai 9 & 4000 & 218.71 & 437.41 & 22.28 & 60 & 60 & OK! \\
\hline Lantai 8 & 4000 & 207.57 & 415.13 & 24.06 & 60 & 60 & $\mathrm{OK} !$ \\
\hline Lantai 7 & 4000 & 195.54 & 391.08 & 25.01 & 60 & 60 & OK! \\
\hline Lantai 6 & 4000 & 183.03 & 366.07 & 26.22 & 60 & 60 & $\mathrm{OK} !$ \\
\hline Lantai 5 & 4000 & 169.92 & 339.84 & 27.42 & 60 & 60 & OK! \\
\hline Lantai 4 & 4000 & 156.21 & 312.42 & 28.43 & 60 & 60 & $\mathrm{OK} !$ \\
\hline Lantai 3 & 4000 & 141.99 & 283.99 & 29.04 & 60 & 60 & $\mathrm{OK} !$ \\
\hline Lantai 2 & 5000 & 127.47 & 254.95 & 35.54 & 75 & 75 & $\mathrm{OK} !$ \\
\hline Lantai 1 (Dasar) & 0 & 109.70 & 219.41 & - & 0 & 0 & - \\
\hline
\end{tabular}

Tabel 9.

Kontrol Simpangan Y Antar Lantai Akibat Beban Gempa Arah Y Struktur Isolasi

Dari dua tabel diatas, dapat disimpulkan bahwa pemodelan struktur memenuhi persyaratan. 


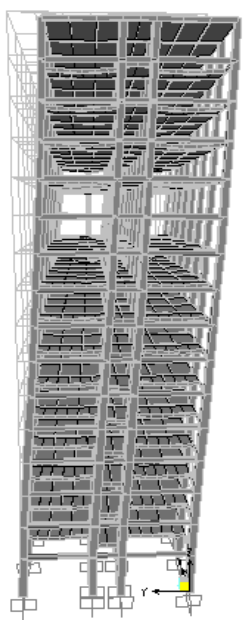

(a)

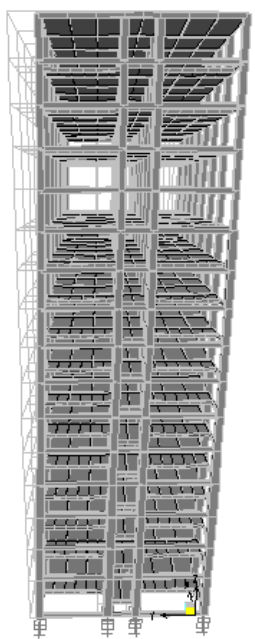

(b)
Gambar 5. Pemodelan 3D Struktur, (a) Fixed Base, (b) Isolation.

\section{Perhitungan Struktur Utama}

Struktur utama menggunakan struktur komposit dimana balok induk komposit dengan steel deck dan kolom baja komposit terselubung beton.

1) Balok Induk berikut:

Hasil perhitungan [12] balok induk adalah sebagai

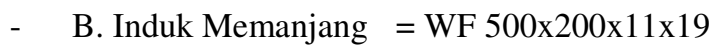

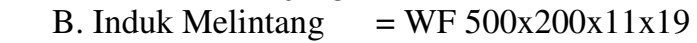

2) Kolom

Hasil perhitungan kolom [12] adalah sebagai berikut:

- K1 (lantai 1-6)

$=\mathrm{K} 700 \times 300 \times 13 \times 24$, beton $850 \times 850$

- $\quad$ K2 (lantai 7-11)

$=\mathrm{K} 600 \times 200 \times 11 \times 17$, beton $750 \times 750$

- $\quad$ K3 (lantai 12-16)

$=\mathrm{K} 500 \times 200 \times 10 \times 16$, beton $650 \times 650$

\section{E. Perhitungan Sambungan}

1) Sambungan Balok Anak - Balok Induk

Sambungan ini menggunakan baut mutu $\mathrm{fu}^{\mathrm{b}}=5000$

$\mathrm{kg} / \mathrm{cm}^{2}$. Sambungan balok anak - balok induk [8], [15] dapat dilihat pada Gambar 6.

2) Sambungan Balok Induk - Kolom

Sambungan ini menggunakan baut mutu tinggi A490 dan tipe rigid connection (T-connection). Sambungan balok induk - kolom [8],[15] dapat dilihat pada Gambar 7.

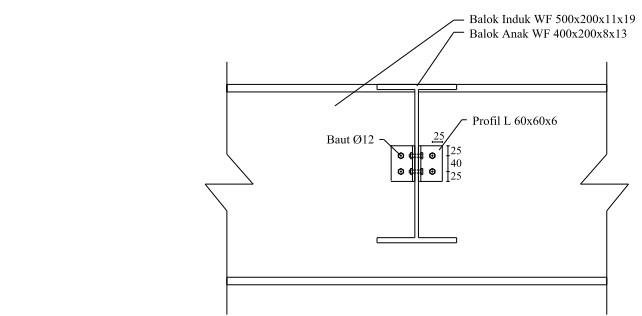

Gambar 6. Sambungan Balok Anak - Balok Induk.

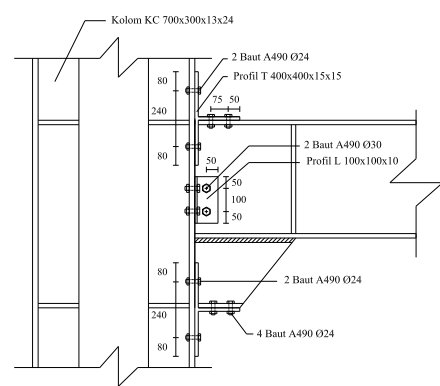

Gambar 7. Sambungan Balok Induk - Kolom.

3) Sambungan Antar Kolom

Sambungan antar kolom ada 2 jenis, yaitu antar kolom seragam dan antar kolom tidak seragam. Sambungan ini menggunakan baut mutu tinggi A490. Sambungan antar kolom [8],[15] dapat dilihat pada Gambar 8 dan Gambar 9.

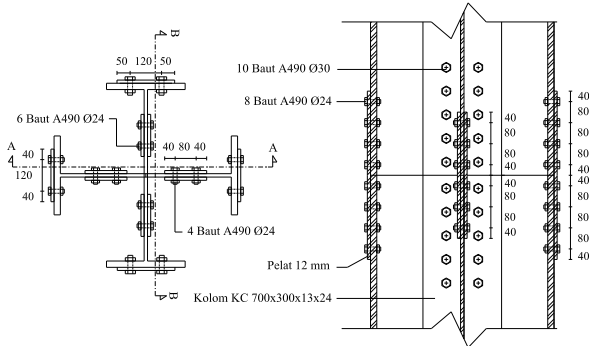

Gambar 8. Sambungan Antar Kolom Seragam.

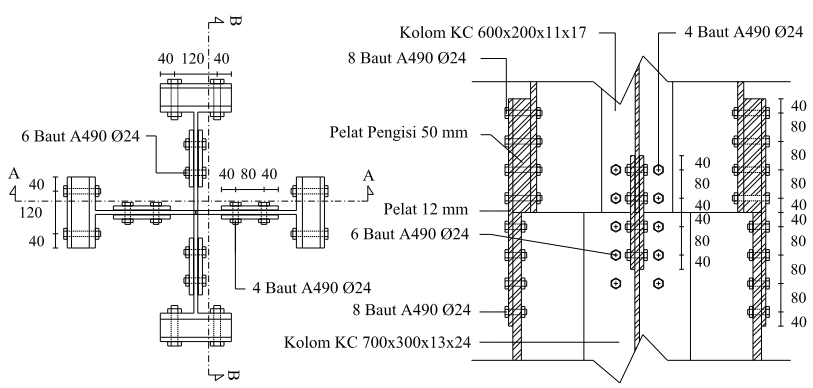

Gambar 9. Sambungan Antar Kolom Tidak Seragam.

4) Sambungan Balok Induk - Pedestal Atas

Sambungan ini menggunakan jenis extended end plate tanpa pengaku (Gambar 10) dengan baut angkur A325 dengan hasil [8],[15] sebagai berikut:

- Sambungan las mutu $F_{E 110 x x}$ dan $a=1 \mathrm{~cm}$

- $\quad$ Sambungan baut angkur $14 \varnothing 24$, panjang angkur $=50$ $\mathrm{cm}$

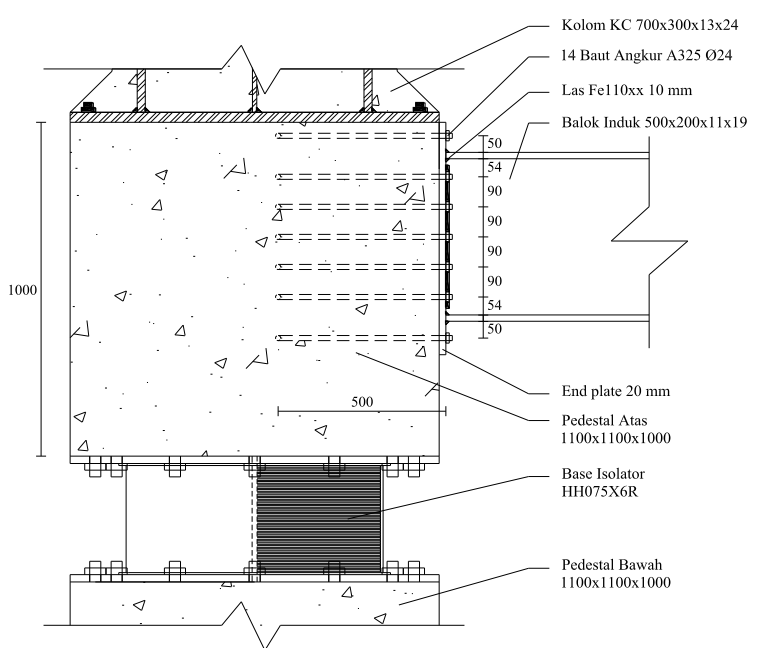

Gambar 10. Sambungan Balok Induk - Pedestal Atas. 
5) Sambungan Base Plate

Sambungan ini menggunakan sambungan las dan baut angkur A325 dengan hasil [8],[15] sebagai berikut:

- $\quad$ Sambungan las mutu $\mathrm{F}_{\mathrm{E} 110 \mathrm{xx}}$ dan a $=1,6 \mathrm{~cm}$

- $\quad$ Sambungan baut angkur $8 \emptyset 24$, panjang angkur $=50$ $\mathrm{cm}$

- Tebal base plate $=3 \mathrm{~cm}$

\section{F. Perhitungan Pondasi}

Berdasarkan data tanah yang ada, pondasi menggunakan tiang pancang spun pile diameter $60 \mathrm{~cm}$ dari PT Wika Beton dengan kedalaman $26 \mathrm{~m}$.

1) Pilecap

Pada studi ini didapatkan 2 jenis pilecap, yaitu:

- $\quad$ Pilecap tipe 1 (3800x2500x1000)

Jumlah tiang pancang 6 buah, tulangan lentur sisi panjang D25-170, dan sisi pendek D25-290 [11].

- $\quad$ Pilecap tipe 2 (5100x6400x1000)

Jumlah tiang pancang 20 buah, tulangan lentur sisi panjang D25-170, dan sisi pendek D25-180 [11].

2) Pedestal

Pada studi ini ada 2 jenis pedestal, yaitu pedestal atas dan pedestal bawah dengan dimensi 1100x1100x1000. Tulangan longitudinal 24D25 dan tulangan transversal Ø13150 [11].

3) Balok Sloof

Berdasarkan hasil perhitungan, didapatkan dimensi balok sloof adalah 400x600. Dengan tulangan positif 2D16 dan tulangan negatif 4D16 sisi tumpuan sedangkan tulangan positif 4D16 dan tulangan negatif 2D16 untuk sisi lapangan [11].

\section{KESIMPULAN DAN SARAN}

\section{A. Kesimpulan}

Dari perhitungan struktur dan analisa yang telah dilakukan, maka diperoleh beberapa kesimpulan dari studi ini.

Pertama, didapatkan struktur sekunder meliputi pelat atap menggunakan steel deck dari brosur super floor deck dengan tebal pelat beton $9 \mathrm{~cm}$ dan tulangan negatif Ø10-200. Pelat lantai menggunakan steel deck dari brosur super floor deck dengan tebal pelat beton $9 \mathrm{~cm}$ dan tulangan negatif $\varnothing 10$ 160. Balok anak yang terdiri dari 5 jenis untuk balok anak lantai dan 4 jenis untuk balok anak atap. Struktur tangga dengan balok penumpu dan balok utama menggunakan profil WF $250 \times 125 \times 5 \times 8$. Struktur ramp dengan balok penumpu dan balok utama menggunakan profil WF 350x175x6x9. Struktur lift dengan balok penggantung menggunakan profil WF 300x150x5,5x8.

Kedua, struktur primer yang meliputi balok induk dan kolom didesain komposit baja-beton. Struktur balok induk didesain komposit dengan menggunakan shear connector tipe stud dengan menggunakan profil WF 500x200x11x19. Struktur kolom didesain komposit terselubung beton dengan profil kingcross $\mathrm{K} 700 \times 300 \times 13 \times 24$ untuk lantai 1-6 dengan penampang beton $850 \times 850, \mathrm{~K} 600 \times 200 \times 11 \times 17$ untuk lantai 7-11 dengan penampang beton $750 \times 750$, dan
K500x200x10x16 untuk lantai 12-16 dengan penampang beton $650 \times 650$.

Ketiga, didapatkan dimensi base isolator tipe high damping rubber bearing untuk kolom internal dan kolom eksternal dengan diameter rubber $750 \mathrm{~mm}$ (HH075x6R) dari brosur bridgestone : Seismic isolation product line-up.

Keempat, struktur pondasi merupakan tipe pondasi dalam dengan tiang pancang spun pile diameter $60 \mathrm{~cm}$ dari PT Wika Beton dengan kedalaman 26 meter. Didapatkan 2 jenis pilecap yaitu pilecap tipe 1 dengan dimensi $3800 \times 2500 \times 1000$ dan pilecap tipe 2 dengan dimensi 5100x6400x1000 dengan tulangan masing-masing dipasang dua arah, sisi panjang dan sisi pendek.

\section{B. Saran}

Perlu dilakukan studi lebih lanjut mengenai perencanaan struktur menggunakan base isolator khususnya tipe high damping rubber bearing (HDRB) dengan acuan SNI 1726:2012 maupun peraturan-peraturan lainnya, sehingga terlihat keunggulan penggunaan base isolator dibandingkan struktur fixed base.

Diharapkan perencanaan dapat dimodelkan semirip mungkin dengan kondisi lapangan sehingga didapatkan struktur yang ekonomis, efisien, dan mudah dalam pelaksanaan.

\section{DAFTAR PUSTAKA}

[1] D. Sukamta, "Hidup Bersama Gempa di Jakarta," Kompas, Jakarta, 2006.

[2] W. Yunita, "Mikrozonasi Gempa Jakarta dengan Periode Ulang 500 Tahun,” Institut Teknologi Bandung, 2012.

[3] Z. Arifin, "Modifikasi Perancangan Struktur Komposit Baja dan Beton pada gedung RSUD Kepanjen-Malan," Institut Teknologi Sepuluh Nopember, 2011.

[4] S. Izzati, "Modifikasi Perancangan RSUD Koja Jakarta Menggunakan Struktur Komposit Baja Beton,” Institut Teknologi Sepuluh Nopember, 2016.

[5] D. Qoernia, Penentuan Nilai Parameter Dynamic Absorber Berbasis Frekuensi. Surabaya: ITS Press, 2010.

[6] E. Suardi, "Rubber Bearing Isolator Sebagai Sistem Penahan Gempa pada Bangunan Hotel Ibis Padang," Jakarta, 2013.

[7] N. Heriandes, "Perancangan Modifikasi Struktur Gedung Dinas Prasarana Jalan, Tata Ruang dan Permukiman Provinsi Sumatera Barat Menggunakan High Damping Rubber Bearing (HDRB).," Institut Teknologi Sepuluh Nopember, 2015.

[8] Badan Standarisasi Nasional, "SNI 03-1729-2002 Tata Cara Perencanaan Struktur Baja Untuk Bangunan Gedung," Jakarta 2002.

[9] Badan Standarisasi Nasional, "SNI 1726:2012 Tata Cara Perencanaan Ketahanan Gempa Untuk Bangunan Gedung," Jakarta.

[10] Badan Standarisasi Nasional, "SNI 1727:2013 Beban Minimum Untuk Perancangan Bangunan Gedung dan Struktur Lain," Jakarta, 2013.

[11] Badan Standarisasi Nasional, "SNI 2847:2013 Tata Cara Perhitungan Struktur Beton Untuk Bangunan Gedung,' Jakarta 2013.

[12] Badan Standarisasi Nasional, "SNI 1729:2015 Spesifikasi Untuk Bangunan Gedung Baja Struktural,” Jakarta, 2015.

[13] Direktorat Penyelidikan Masalah Bangunan, "Peraturan Pembebanan Indonesia Untuk Gedung 1983,” Bandung, 1983.

[14] J. M. Kelly and F. Naeim, Design of Seismic Isolated Structure. From Theory to Practice. New York: John Wiley \& Sons Inc, 1999.

[15] M. Ibrahim and Isdarmanu, Buku Ajar Struktur Baja I. Surabaya: Teknik Sipil ITS, 2006. 